\title{
SOME BEES FROM UTAH
}

\author{
By T. D. A. Cockerell,
} University of Colorado, Boulder, Colo.

Comparatively little is known of the bees of Utah, so I heard with great satisfaction that Professor Vasco M. Tanner and his associates at Brigham Young University were vigorously collecting and studying the Hymenoptera of their state. They will undoubtedly have a rich field for interesting discoveries. At the present time I record a small series of bees, many of them new to Utah, sent to me by Professor Tanner.

Nomada civilis Cress. $\quad$ + 662 (Clarence Cottam)

Nomada (Gnathias) bella Cress. 1637 (C. J. D. Brown)

Triepeolus wyomingensis Ckll, $20^{x}$, Sheep Creek, Duchesne Co.

These show that the black mark on first abdominal segment varies from a well defined transverse band, rounded at ends, to an irregular mark, broad in middle, but linear and partly broken laterally.

Triepeolus tanneri n. sp.

$\sigma^{\top}$ Length about $10.5 \mathrm{~mm}$; robust, black, including mandibles, antennæ, tegulæ (except dark brown margin) and legs (except tarsi; dull red at apex), spurs black; ornaments cream-color; eyes light green, purplish only to a slight degree at extreme base; face narrow; a patch of glittering white hair lateral of each antenna; clypeus dull, minutely and densely granular-punctate all over; mesothorax strongly, more or less confluently punctured, glittering between the punctures; a pair of not very distinct dagger-shaped pubescent marks anteriorly, the base on anterior margin of mesothorax, approached by, but not touching. pubescence of sides; scutellum strongly bigibbous; mesothorax dull, granular and rough, bare except a little hair at its upper end; wings very brown; abdomen with six even apical bands, and an anterior one, interrupted in middle, on first segment (the apical one on first almost interrupted); 
black area on first segment a very broad (anteroposteriorly) but not very long transverse band, clean cut, with broadly rounded ends; band on second segment somewhat enlarged at sides, but with no anterior extension; venter black, not banded. Farr West, Utah (C. J. D. Brown). In my MS. table it runs to $T$. lineatulus Ckll., which differs at once by the transverse mark on pleura, the anterior extensions of band on second segment, the much longer black band on disc of first segment, etc. It runs out in all other tables.

Epeolus dacotensis Stevens. क Sheep Creek, Duchesne Co., June 1926. Previously known from North Dakota. Anthophora occidentalis Cress., $\sigma^{T}$ Sheep Creek (Tanner, Cottam) Anthophora urbana Cress., o Springville (C. Lynn Hayward)

Melissodes alopex n. sp.

$\sigma^{7}$ Runs in my table (Tr. Am. Ent. Soc., 1906) to $M$. menuacha Cress., which it resembles in size and general appearance. It differs thus: pubescence in general much redder, fox-red on thorax and very bright on tibiæ and tarsi; third antennal joint shorter (its length about 990 microns); eyes darker green; wings strongly blackish, outer nervures black; second cubital cell very broad, not appreciably narrowing above; hind margins of abdominal segments not at all hyaline; second segment densely hairy at base, and with a median fulvous band; third to fifth with the exposed parts densely covered with fulvous hair, except broad apical margin of third, and narrow brownish margin of fourth; apex black haired.

Duchesne, Utah, July 1926 (Tanner) There is also a strong resemblance to $M$. sabinensis Ckll., from Arizona, but that has a broader, much more closely felted abdomen, and a much narrower face.

Melissodes agilis Cress. $\sigma^{7}$ Zion National Park (Tanner) Melissodes agilis aurigenia Cress., $0^{\top}$ Zion National Park (Tanner) Megachile sapellonis Ckll. \& Aspen grove near Timpanogas (Tanner) Described from New Mexico. 
Megachile perihirta Ckll. o' Sheep Creek, June, (Tanner)

Megachile manifesta Cress. \& St. George, Aug. (Tanner)

Anthidium tenuiflorce Ckll. o Triplett Farm, Burnt Fork, June

(Hayward); Summit Danials (sic) Canyon, 8000 ft., July (Hayward)

Alcidamea hypocrita Ckll. \& Wellsville Canyon, June (Brown)

Osmia lignaria propinqua Cress., $\&$ Provo, April (Hayward); Wellsville Canyon, June (Hayward)

Osmia nassa Ckll. o Summit Danials Canyon, $8000 \mathrm{ft}$., July (Hayward). In this specimen the thorax is dorsally black. Described from California.

Osmia melanotricha Lovell \& Ckll. \& Triplett Farm, Burnt Fork, June (Hayward) Described from Maine.

Ceratina submaritima Ckll. \& Wellsville Canyon, June (Tanner) Known from the Pacific coast; I did not expect it so far inland.

Spinoliella scitula Cress., \& Fort Bridges, June (Hayward)

Agapostemon virescens Fabricius, \& Wellsville Canyon, June (Tanner)

Halictus lerouxii Lepeletier, $q$. No. 23. A small neat form, such as I have found at Florissant, Colo. Compared with Illinois material it looks distinct, but is surely the same species.

Halictus (Seladonia) meliloti Ckll. ㅇ Provo, May (Hayward) 

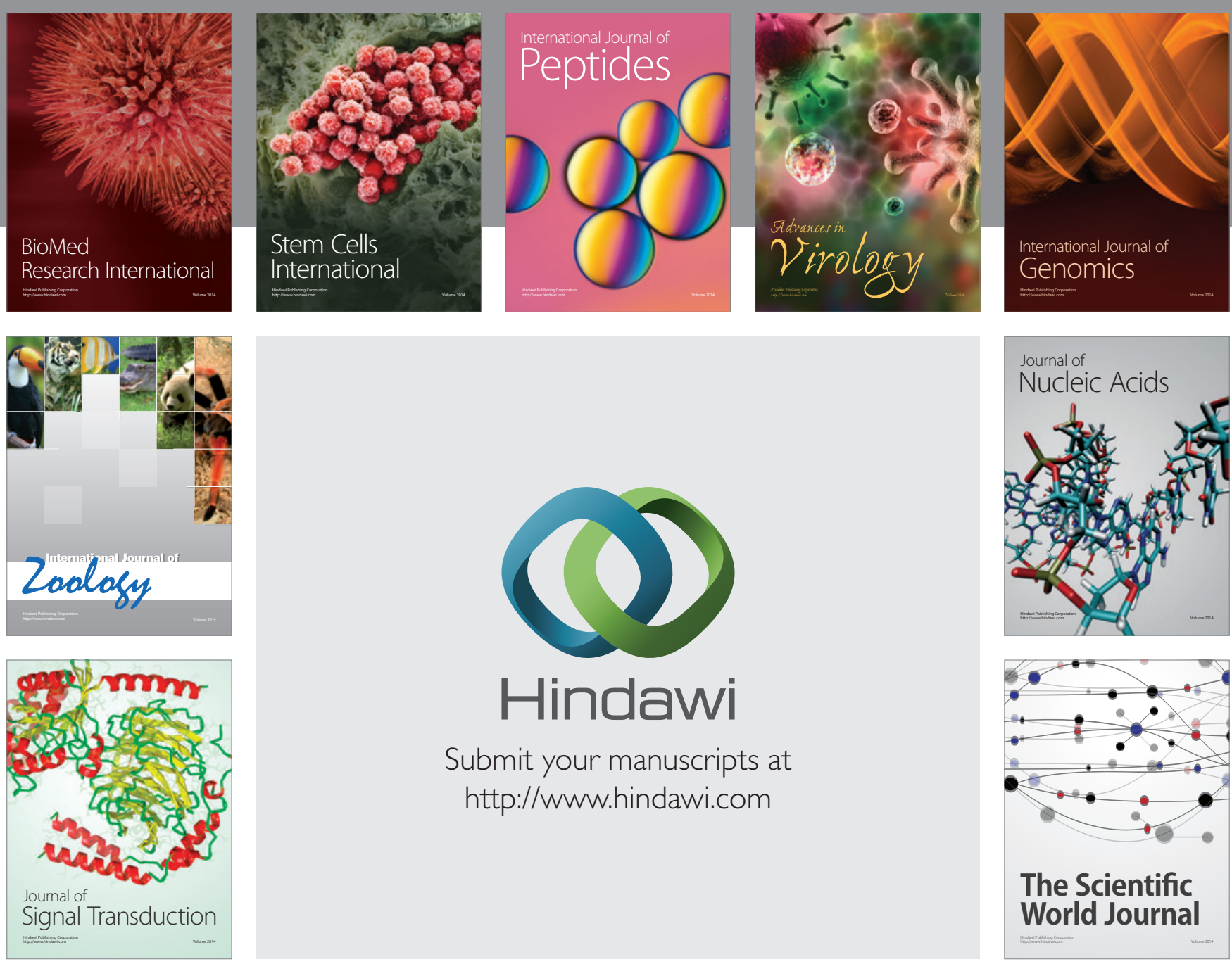

Submit your manuscripts at

http://www.hindawi.com
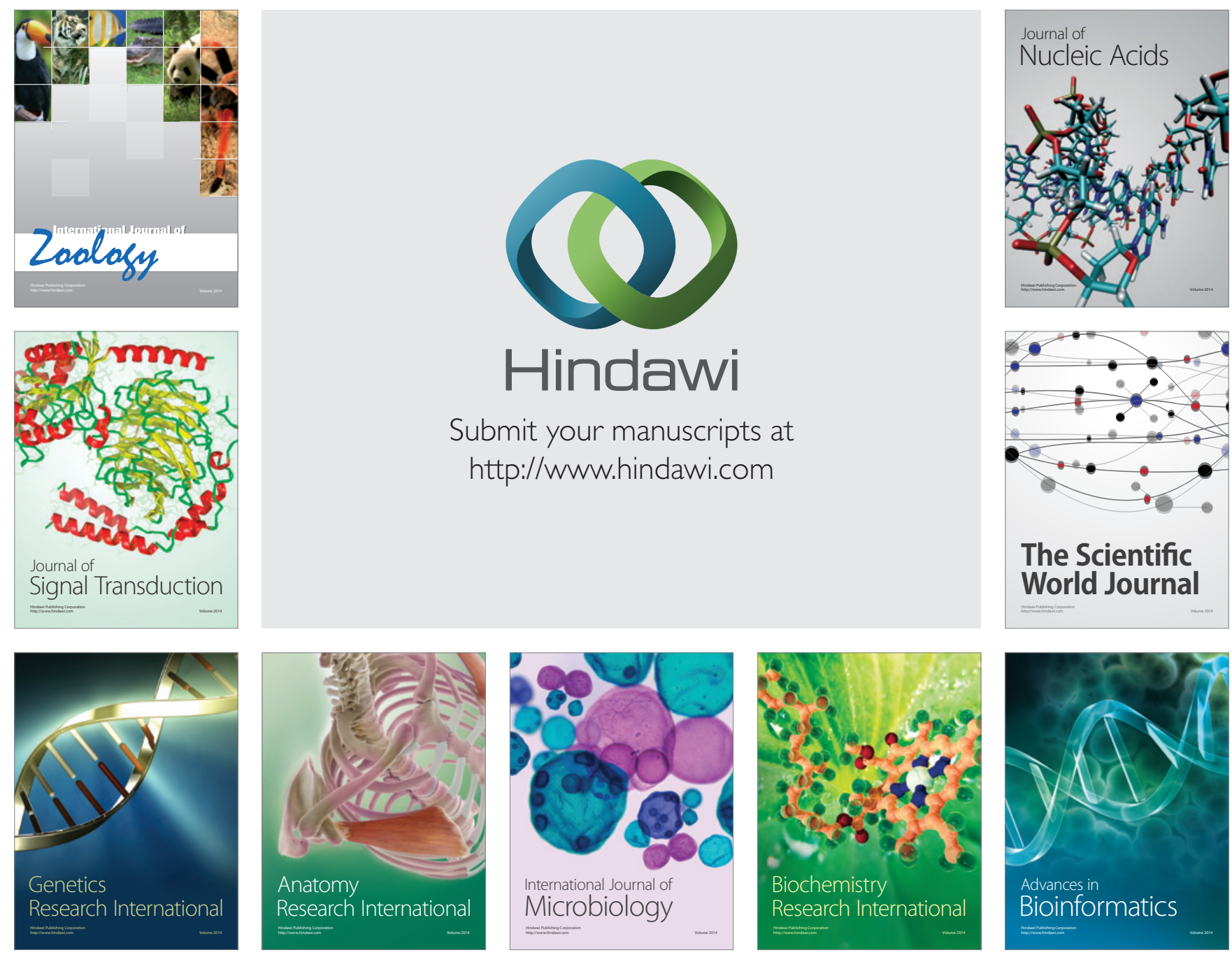

The Scientific World Journal
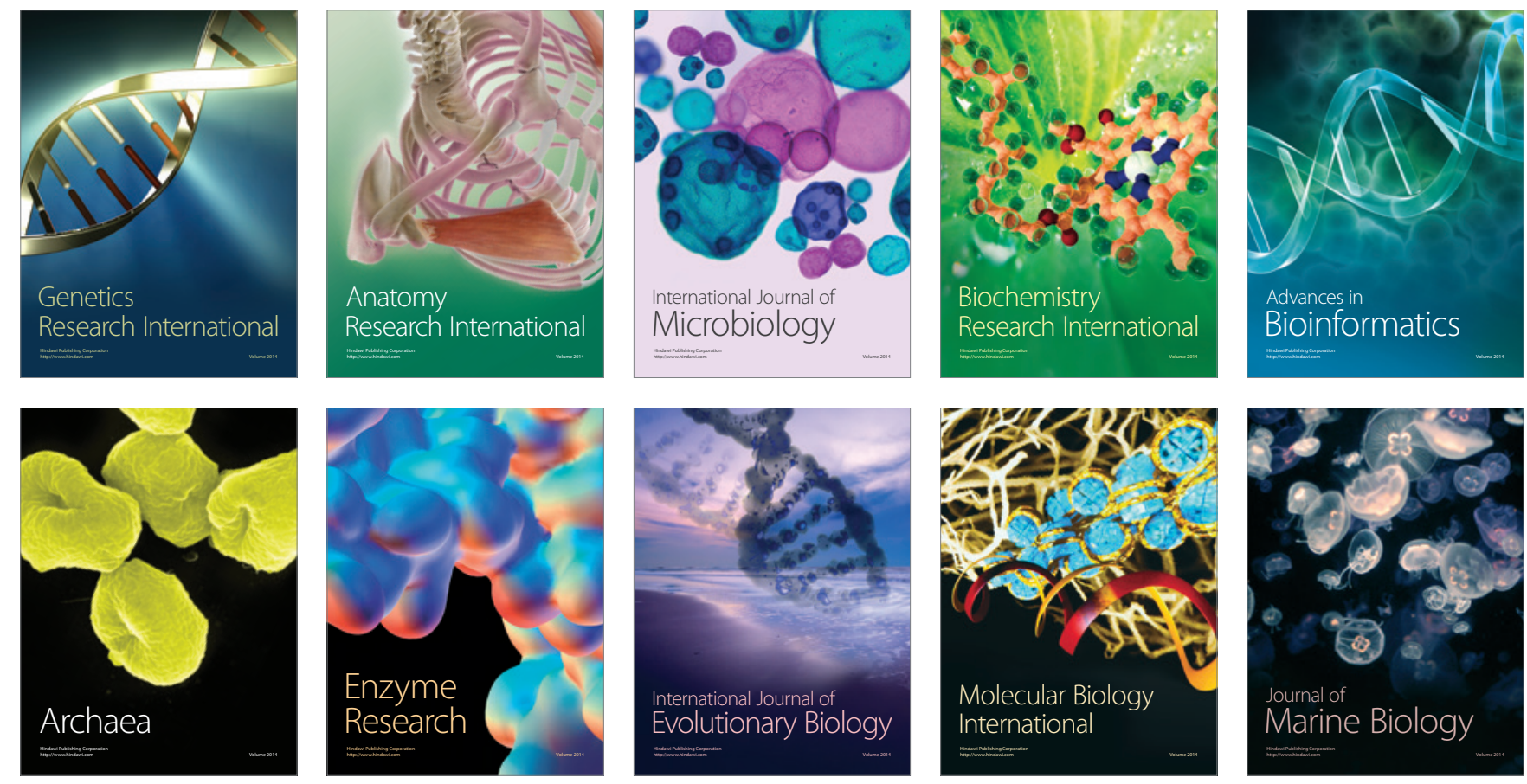